\section{Ks. Dariusz Kotecki}

Uniwersytet Mikołaja Kopernika w Toruniu dkotecki@umk.pl

ORCID: 0000-0002-0763-0430

DOI: http://dx.doi.org/10.12775/BPTh.2021.005
Biblica

et

Patristica

Thoruniensia

14 (2021) 1: 113-120

ISSN (print) 1689-5150

ISSN (online) 2450-7059

\title{
Przywrócić nowotestamentowy List św. Judy współczesnej biblistyce i dydaktyce biblijnej. Refleksji kilka nad opracowaniem: K. Wojciechowska, M. Rosik, Oczekując miłosierdzia. Komentarz strukturalny do Listu św. Judy, Wydawnictwo Naukowe ChAT, Warszawa 2020, ss. 460
}

\section{To restore the New Testament Epistle of St. Jude to contemporary biblical studies and biblical didactics. Reflections on the study: Oczekując miłosierdzia. Komentarz strukturalny do Listu św. Judy by K. Wojciechowska, M. Rosik, Wydawnictwo Naukowe ChAT, Warszawa 2020, 460 pp.}

Streszczenie. Autor artykułu na kanwie opracowania K. Wojciechowskiej i M. Rosika, Oczekując miłosierdzia. Komentarz strukturalny do Listu św. Judy (Wydawnictwo Naukowe ChAT, Warszawa 2020), odpowiada na pytanie: czy są przesłanki, aby krótki, zawierający zaledwie 25 wierszy, List św. Judy z Nowego Testamentu, przywrócić zarówno biblistyce, teologii oraz dydaktyce biblijnej, w tym duszpasterstwu biblijnemu. Odpowiedź jest pozytywna, ponieważ temu listowi towarzyszy: 1) zbyt małe zainteresowanie w samej biblistyce; 2) prawie całkowita jego nieobecność w dydaktyce, jak i duszpasterstwie biblijnym; 3) niedocenienie jego danych teologicznych w samej teologii, zwłaszcza w chrystologii i soteriologii; 4) skupienie się na stronie parenetycznej tego tekstu, a nie na teologii; 5) częste pomijanie w opracowaniach na temat teologii pierwszych wieków wykorzystywania literatury pozabiblijnej (przykładem takiego wykorzystania jest właśnie List św. Judy).

Abstract. The author of the article on the basis of the study entitled Oczekujac miłosierdzia. Komentarz strukturalny do Listu św. Judy by K. Wojciechowska and M. Rosik (Wydawnictwo Naukowe ChAT, Warsaw 2020), tries to answer the question of whether there are any reasons for restoring this short epistle to biblical studies, theology, and biblical teaching, including biblical pastoral care. The answer is positive as the Epistle of Jude although only 25 verses long is 1) not given sufficient interest in biblical studies; 2) is virtually absent from teaching and biblical ministry; 3 ) its theological data are underestimated in theology, in particular in Christology and soteriology; 4) the parenetic aspect of this text is emphasized, whereas theological aspects are dis- 
regarded; 5) is ignored in studies of the early theology on using extra-biblical literature (an example of such is the Letter of St. Jude).

Słowa kluczowe: List Judy; apokryfy; chrystologia; soteriologia.

Keywords: the Epistle of Jude; apocrypha; Christology; soteriology.

W 2020 r. nakładem Wydawnictwa Naukowego Chrześcijańskiej Akademii Teologicznej w Warszawie ukazała się dwuautorska praca K. Wojciechowskiej i M. Rosika po tytułem Oczekując miłosierdzia. Komentarz strukturalny do Listu św. Judy (Warszawa 2020, ss. 460). Autorzy komentarza pochodzą z dwóch różnych tradycji: luterańskiej (K. Wojciechowska) i katolickiej (M. Rosik) i z dwóch różnych ośrodków naukowych, odpowiednio: Chrześcijańskiej Akademii Teologicznej w Warszawie oraz Papieskiego Wydziału Teologicznego we Wrocławiu. Cały komentarz ma wymiar zatem ekumeniczny, co zresztą można dostrzec w tych jego miejscach, w których autorzy przywołują spojrzenie na różne zagadnienia związane $z$ tym listem, chociażby Marcina Lutra. Opracowanie to pokazuje, że dialog ekumeniczny również na polu naukowym jest możliwy i że na tym polu można przekraczać czy obalać wszelkie podziały. We wstępie do opracowania autorzy podkreślili: „Autorzy opracowania Oczekując miłosierdzia. Strukturalny komentarz do Listu św. Judy mają nadzieję, że przywróci ono Judowemu pismu należne miejsce także we współczesnej refleksji biblistycznej" ${ }^{1}$. Zakres tej nadziei można byłoby poszerzyć jeszcze o refleksję teologiczną i szeroko pojętą dydaktykę biblijną (akademicką i duszpasterską). Rodzi się zatem pytanie, czy są jakieś przesłanki do tego, aby w ogóle podejmować się próby przywrócenia tej krótkiej księgi Nowego Testamentu współczesnej myśli chrześcijańskiej? Niniejszy esej stanowi próbę odpowiedzi na tę kwestię.

Pierwsze pytanie, które należy sobie postawić, to, czy jest w ogóle potrzebny oddzielny komentarz do jednego z listów Nowego Testamentu i to tak krótkiego, zawierającego zaledwie 25 wierszy? Odpowiedź jest ze wszech miar pozytywna. List Judy jest jednym z pism Nowego Testamentu najrzadziej komentowanym w biblistyce współczesnej, zarówno polsko-, jak i obcojęzycznej. Nie zmieniają tego faktu studia szczegółowe - coraz liczniejsze począwszy od

1 K. Wojciechowska, M. Rosik, Oczekując miłosierdzia, s. 33. 
lat 90. XX wieku - dotyczące retoryki, struktury literackiej, krytyki tekstu, użycia w nim literatury pozabiblijnej czy jego teologii. Zastosowano w jego egzegezie wiele metod, które Papieska Komisja Biblijna w Dokumencie z 1993 r. Interpretacja Biblii w Kościele określa jako „nowe metody analizy literackiej”" Obecnie - jak słusznie zauważają sami autorzy komentarza (s. 32) i co pokrywa się z moją wiedzą i doświadczeniem akademickim w tym względzie - trudno jest mówić o jakimś renesansie zainteresowania tym listem na polu badawczym czy dydaktycznym, dotyczącym zarówno auli uniwersyteckich czy biblijnej aktywności duszpasterskiej. List ten jest przedmiotem badań i nauczania niejako „obok” Pierwszego i Drugiego Listu Piotra czy listów powszechnych, o czym mogą świadczyć tytuły wydanych komentarzy zarówno polskich, jak i zagranicznych. Dysproporcje zaś pomiędzy opracowaniami poświęconymi temu listowi a innym tekstom Nowego Testamentu są przeogromne. Dlaczego list, który - jak słusznie podkreślają K. Wojciechowska i ks. M. Rosik - „W pierwotnym chrześcijaństwie musiał cieszyć się wielkim autorytetem, skoro autor Drugiego Listu Piotra zdecydował się niemal w całości włączyć tekst Judy do swojego pisma" ${ }^{3}$, poszedł potem w niezasłużone zapomnienie czy zaniedbanie? Nie ma chyba jednoznacznej odpowiedzi na tę kwestię. Być może stało się tak przez sam fakt włączenia go do $2 \mathrm{P}$, być może z racji samej jego długości, być może z powodu odwoływania się w nim przez autora do literatury apokryficznej, która w pewnych okresach rozwoju myśli chrześcijańskiej była na „cenzurowanej pozycji”. Racje za takim stanem rzeczy zostały znakomicie wyłożone przez autorów we „Wstępie”, które zawiera syntetyczne status quaestionis w tej materii. W takim kontekście należy spojrzeć na niniejszą publikację z wielkim uznaniem. Na pewno przedsięwzięcie K. Wojciechowskiej i M. Rosika jest bez jakiegokolwiek precedensu zarówno w biblistyce polskiej, jak i światowej, ponieważ ten krótki list doczekał się nie tylko odrębnego, ale także niezwykle szczegółowego komentarza. Dobrze się stało, że na końcu tego opracowania, zostało zamieszczone streszczenie $\mathrm{w}$ języku angielskim, które być może przyczyni się do zauważenia tak unikatowego dzieła przez wydawców światowych.

$\mathrm{Na}$ pewno drogą przywrócenia tego listu myśli biblijnej, teologicznej czy dydaktyce biblijnej jest krytyczna prezentacja tego wszystkiego, co wchodzi w zakres tzw. krytyki historycznej oraz analizy literackiej. „Wprowadzenie” do komentarza (s. 29-96) zawiera wiele bardzo cennych informacji, dyskusji na te-

\footnotetext{
2 Zob. Interpretacja Biblii w Kościele, s. 33-40.

3 K. Wojciechowska, M. Rosik, Oczekując miłosierdzia, s. 33.
} 
mat świadectw tekstowych, kanoniczności tego listu, autorstwa, dat powstania, odbiorców, słownictwa i stylu, gatunku literackiego i struktury. Całe wprowadzenie nie zawiera jednak - i to jest jego wielki walor - definitywnych odpowiedzi na postawione w podtytułach kwestie, ale jest zaproszeniem do dalszych dyskusji, która wstępnie toczy się już na kartach opracowania. Bardzo ciekawe jest ujęcie problemu kanoniczności Listu Judy. Autorzy podkreślają, że należy je rozpatrywać na dwóch płaszczyznach. Po pierwsze jako pisma normatywnego dla Kościoła ${ }^{4}$, po drugie zaś w perspektywie obecności w nim odwołań do pism niekanonicznych (chodzi tutaj przede wszystkim o cytat z 1 Hen 1,9 w Jud 14-15, który jest traktowany jako ustęp z pism prorockich czy dyskretne nawiązanie do literatury międzytestamentowej, np. Testamentu Mojżesza w Jud 9) ${ }^{5}$. Na tle dyskusji o kanoniczności w tej drugiej perspektywie można zrozumieć, dlaczego List Judy był przez wielu traktowany z pewnego rodzaju podejrzeniem. Autorzy komentarza wiele uwagi poświęcili źródłom literackim Listu św. Judy oraz sposobowi ich wykorzystania. Ich wskazania na źródła znajdują swoje rozwinięcie w samej treści komentarza, gdzie ukazują wykorzystanie przez Judę materiałów pochodzących z tradycji judaistycznej, jak i hellenistycznej, które świadczy nie tylko o ich znajomości ze strony autora listu, jak i jego adresatów, ale także pokazuje sposoby argumentowania chrześcijańskiego w starożytności, które wykorzystując pewne teksty i literackie metody (żydowskie i hellenistyczne) interpretacji tekstu podporządkowują je chrystocentrycznej hermeneutyce. Wielkim atutem komentarza jest przytaczanie całych passusów z pozabiblijnych tekstów źródłowych zarówno żydowskich, jak i greckich oraz pochodzących z tradycji wczesnochrześcijańskiej i patrystycznej. Stanowi to wielkie ułatwienie dla czytelnika, który ma owszem możliwość sięgnięcia do literatury biblijnej, ale miałby wiele trudności w odnalezieniu paraleli pozabiblijnych. W kluczu przywracania Listu Judy współczesnej biblistyce otwiera się możliwość dalszej pracy badawczej, włączającej ten list do nurtu badań zajmujących się źródłami pism nowotestamentowych.

Oboje badacze, K. Wojciechowska i M. Rosik, idąc za zestawieniem argumentów za wczesnym i późnym datowaniem, zaproponowanym G.L. Greena, tj. autorstwo, doktryna i instytualizacja Kościoła, idee fałszywych nauczycie-

4 Tutaj dotykamy problemu relacji między zagadnieniem kanoniczności w sensie aktywnym, tj. kanonu jako normy wiary i obyczajów dla wspólnoty, a kanonicznością w sensie pasywnym (zbiór ksiąg zawierających te normy).

5 K. Wojciechowska, M. Rosik, Oczekujac miłosierdzia, s. 41. 
li, relacje do Pawła, rozumienie terminu apostoł, relacja Jud i $2 \mathrm{P}^{6}$, prowadzą ożywioną dyskusję na temat datacji pisma. Wszystkie przedstawione argumenty są omówione o wiele szerzej niż w dziele Greena. W kluczu jednak przywracania Listu św. Judy biblistyce i teologii może przydałoby się spojrzeć na problem datacji tego dzieła z perspektywy jeszcze jednej danej teologicznej, o której zresztą autorzy opracowania wielokrotnie wspominają już w samym komentarzu, tj. idei preegzystencji Jezusa Chrystusa, która w Jud jest implikowana, chociażby wspomnieć w. 5-7, a która była obecna w myśli wczesnochrześcijańskiej, zarówno w myśli św. Pawła, w ewangeliach synoptycznych czy Ewangelii według św. Jana ${ }^{7}$. Pozostaje zatem pytanie otwarte, czy obecność tej idei nie otwiera kolejnych możliwości w odkrywaniu datacji listu? Sam charakter prezentowanej w nim chrystologii, którą nazwałbym narracyjną, może świadczyć na korzyść wczesnego datowania tego listu. Chrystologia zresztą jest według mnie kolejnym punktem do dyskusji nad przesłaniem listu i także sposobem przywracania go biblistyce, teologii i nauczaniu. Komentarz ofiaruje w tym względzie bardzo wiele, mimo że czytelnik nie znajdzie w nim osobnego omówienia zagadnień chrystologicznych. Relacja Jezusa Chrystusa do jedynego Boga Izraela powinna doczekać się rozwinięcia. Ciekawą rzeczą jest fakt, że R. Bauckham, autor komentarza i wprowadzeń do tego listu ${ }^{8}$, w swoim zbiorze esejów chrystologicznych zatytułowanym Jesus and the God of Israel. God Crucified and Other Studies on the New Testament's Christologuy of Divine Identity, który w pewnym sensie podsumowuje jego badania nad chrystologią Nowego Testamentu, w ogóle nie zajmuje się chrystologią tego listu, a jedynie w trzech miejscach wzmiankuje List Judy obok innych tekstów Nowego Testamentu: w. 14 na s. 220 oraz w. 25 na s. 133 i $142^{9}$.

Autorzy, opierając się na zaproponowanej przez siebie strukturze tekstu i przeprowadzając wnikliwe jego analizy, dochodzą do wniosku, że List Judy wcale - jak podkreśla wielu egzegetów - nie koncentruje się na wątkach parenetycznych, które bez wątpienia są w nim obecne, ale na teologii, zwłaszcza soteriologii i chrystologii. Recenzowane opracowanie otwiera zatem List Judy

6 G.L. Green, Jude and 2 Peter, s. 98-99.

7 Zob. między innymi S.J. Gathercole, The Preexistent Son; Ch. Tilling, Paul's Divine Christology.

8 R. Bauckham, Jude, 2 Peter; idem, Jude, Epistle of; s. 1098-1103; idem, Jude, s. 1184-1186 .

9 Idem, Jesus and the God of Israel. 
na dalszą refleksję egzegetyczno-teologiczną. Dla mnie osobiście komentarz ten jest zaproszeniem do odkrywania jego danych teologicznych i do dalszych wnikliwych porównań z tekstami nowotestamentowymi, które są przykładami teocentryzmu chrystologicznego ${ }^{10}$.

Mam nadzieję, że tymi kilkoma refleksjami udowodniłem tezę o konieczności przywrócenia Listu św. Judy biblistyce, teologii i dydaktyce. Na koniec jeszcze kilka uwag dotyczących samego komentarza. Całe wprowadzenie jest kopalnią wiedzy na temat tego listu. Autorzy konsultują i dyskutują w kwestiach szczegółowych z wieloma biblistami. Ich wprowadzenie do listu jest ze wszech miar krytyczne. Dobrze się stało, że autorzy nie poszli ścieżką większości komentatorów ksiąg biblijnych, którzy zazwyczaj we wprowadzeniach umieszczają także teologię danej księgi, co powoduje, że późniejszy komentarz egzegetyczny wydaje się oderwany od teologii, a czym, jak nie „sztuką dla sztuki”, staje się egzegeza, która nie prowadzi do teologii, lub dokąd prowadzi teologia niewyprowadzona z egzegezy, o czym bardzo mocno przypomniał papież Benedykt XVI w adhortacji Verbum Domini.

Sam komentarz właściwy świadczy o znakomitym warsztacie filologicznym, egzegetycznym i teologicznym autorów. Komentarz ten rożni się od wielu komentarzy biblijnych płynnością i logicznością wywodu oraz przystępnością przekazu. Nie spotkamy w nim urwanych zdań, suchych danych filologicznych, semantycznych i syntaktycznych zupełnie niepowiązanych ze sobą (taki jest często grzech pierworodny wielu komentarzy biblijnych). Całe analizy różnego rodzaju służą ukazaniu głębi teologicznej. Na wielkie uznanie zasługują analizy porównawcze $\mathrm{z}$ literaturą pozabiblijną. Komentarz ten znakomicie wpisuje się także w nurt badań biblijnych podkreślających jedność Biblii. Jest zatem przykładem egzegezy kanonicznej.

$\mathrm{Na}$ sam koniec mam jedną uwagę krytyczną, która dotyczy samego tytułu. Zamiast „Oczekując miłosierdzia. Komentarz strukturalny do Listu św. Judy” lepszym byłby tytuł poszerzony: „Oczekując miłosierdzia. Wprowadzenie i komentarz strukturalny do Listu św. Judy”. Taki tytuł odpowiadałby bardziej zawartości publikacji, w której wyraźnie można odróżnić dwie części: „Wprowadzenie” i „Komentarz strukturalny”.

Podsumowując, należy się cieszyć, że w Polsce znalazło się dwoje znakomitych biblistów, którzy postawili sobie za punkt honoru przywrócić List Judy refleksji biblistycznej. Ten komentarz może stać się także impulsem do

10 Zob. D. Kotecki, Jezus a Bóg Izraela. 
dalszych badań nad wykorzystaniem w Nowym Testamencie, jak i całej literaturze wczesnochrześcijańskiej literatury pozabiblijnej; nad teologią, zwłaszcza soteriologią i chrystologią nowotestamentową; nad wczesnochrześcijańskimi sposobami argumentacji teologicznej i parenetycznej. Nie mam wątpliwości, że do tego komentarza mogą sięgnąć i - mam nadzieję, że sięgną - nie tylko "zawodowi bibliści”, lecz także rzesze osób, dla których Biblia jest czymś ważnym. Zachowując cały krytyczny aparat naukowy, komentarz ten jest niezwykle przystępny. Wypada tylko pogratulować jego autorom.

Odpowiedź na pytanie, czy cel, jaki postawili sobie autorzy opracowania Oczekując miłosierdzia. Strukturalny komentarz do listu św. Judy, tj. przywrócenie pismu Judowemu należytego miejsca także we współczesnej refleksji biblistycznej i teologicznej, został osiągnięty, pokaże przyszłość. Bez wątpienia komentarz ten można potraktować, używając terminologii z zakresu analizy narracyjnej, jako „lukę narracyjną” i to „lukę permanentną”, podobną do tej, która przybrała postać pytania końcowego w Księdze Jonasza (Jon 4,10-11), która jest próbą pobudzenia czytelnika do refleksji nad postawą Boga i Jonasza $^{11}$. Należy żywić tylko nadzieję, że bibliści polscy, mając do dyspozycji tak znakomity i inspirujący komentarz dwójki badaczy „po fachu”, nie postawią go tylko na półkach swoich bibliotek, ale będzie on dla nich inspiracją do dalszych badań, wszak pobudza on do stawiania pytań, w odpowiedzi na które należy dokonać dalszych badań porównawczych Listu Judy z innymi księgami Nowego Testamentu.

\section{Bibliografia}

Bauckham R., Jude, 2 Peter, WBC 50, Waco 1983.

Bauckham R., Jude, Epistle of: w: The Anchor Bible Dictionary, v. 3, red. D.N. Freedmann, New York 1992, s. 1098-1103.

Bauckham R., Jude, w: The Harper Collins Bible Commentary, red. J.L. Mays, San Francisco 2000, s. 1184-1186.

Bauckham R., Jesus and the God of Israel. God Crucified and Other Studies on the New Testament's Christology of Divine Identity, Grand Rapids-Cambridge 2008.

Gathercole S.J., The Preexistent Son. Recovering the Christologies of Matthew, Mark, and Luke, Grand Rapids-Cambridge 2006.

11 Na ten temat zob. W. Pikor, „Luka” jako strategia narracyjna w Księdze Jonasza, Biblica et Patristica Thoruniensia 2 (2009), s. 13-36. 
Green G.L., Jude and 2 Peter, Grand Rapids 2013.

Interpretacja Biblii w Kościele. Dokument Papieskiej Komisji Biblijnej z komentarzem biblistów polskich przekład i redakcją R. Rubinkiewicz, RSB 4, Warszawa 1999

Kotecki D., Jezus a Bóg Izraela w Apokalipsie św. Jana, Scripta Theologica Thoruniensia 27, Toruń 2013.

Pikor W., „Luka” jako strategia narracyjna w Księdze Jonasza, Biblica et Patristica Thoruniensia 2 (2009), s. 13-36. DOI: http://dx.doi.org/10.12775/BPTh.2009.001.

Tilling Ch., Paul's Divine Christology, Grand Rapids - Cambridge 2012.

Wojciechowska K., Rosik M., Oczekując miłosierdzia. Komentarz strukturalny do Listu św. Judy, Wydawnictwo Naukowe ChAT, Warszawa 2020. 